\title{
Design of Healthy Youth Edition Teens Based Game
}

\author{
Enggar Dwi Utami ${ }^{1}$, Hendra Prasetya ${ }^{2}$, Erdhi Widyarto Nugroho ${ }^{3}$ \\ Information System Department, Faculty of Computer Science \\ Soegijapranata Catholic Univercity, Semarang, Indonesia \\ enggadwiutami@gmail.com ${ }^{1}$, hendra@unika.ac.id ${ }^{2}$,erdhi@gmail.com
}

\begin{abstract}
In Indonesia, there are many promiscuity cases such as brawl, drug dealers and free sex among students. Therefore, the importance of having the social skills to dare to take a firm stance, to reject the negative offer of the environment needs to be owned by a teenager. In addition to the importance of self-awareness, to keep teenagers in Indonesia is not easy to fall into a healthy association it is also necessary to help socialize and provide education about healthy association for today's teenagers.

Through the design of the game Teen Society, adolescents aged 11-24 years provided education about healthy association through mobile games.
\end{abstract}

Keyword- game design, education, healthy association

\section{INTRODUCTION}

Intercourse is part of the process of social interaction between individuals to their social environment. There are two kinds of intercourse, namely healthy association and unhealthy association. Healthy association is in accordance with social values and norms prevailing in the community and bring a positive influence for one's development. While unhealthy association is harmful to self and others [1]. In adolescence, social intercourse has a great influence, because at that age the strength and importance of friendship and the intensity of time spent with peers more [2].
Basically the tendency of teenagers to do negative actions that ultimately harm the future is due to the influence of peers. Friends can interact with each other even at risk, for example a teenager is more likely to start smoking when a friend is already smoking. The strength and importance of friendship and the intensity of time spent with peers is greater in adolescence [3].

Therefore, for teenagers are not easily affected in a negative environment it is also necessary efforts to help socialize and provide education about healthy association for teenagers today.

In line with the progress of technology and information growing, can be used to create media as an effort to help disseminate and provide education about healthy association for teenagers.

The purpose of this paper is to design educational media about the healthy association of teenagers packed in the game.

\section{LITERATURE REVIEW}

\section{A. INTERCOURSE}

Interaction is the interaction between people with each other. In the daily social process there has been contact between someone with other people as well as in social interaction occurs the process of mutual influence. Intercourse includes the relationship 
between individuals and groups directly to give effect to the behavior in life [4].

\section{B. KIND OF INTERCOURSE}

Based on the nature of the relationship can be divided into two, namely the association of a positive and negative association:

a. Positive Interaction

Positive interaction is a social based on values, norms and religions and followed by activities that are positive as well.

b. Negative Interaction

Negative intercourse is a relationship that is deviating from the boundaries of obligations, rules, demands, culture, terms and feelings of shame [5].

Meanwhile according to the theory of sociology, interaction is divided into two, namely healthy association and unhealthy association. Healthy interaction is a social interaction that leads to social norms prevailing in society and bring a positive influence to the development of one's personality. While unhealthy interactions are social interactions that lead to behaviors that are detrimental to themselves or to others [2].

\section{YOUTH}

Adolescence comes from the Latin language is adolescere which means to grow or grow into adulthood. Psychologically adolescence is a period in which the age of the individual has been able to integrate with the adult society, the age where they feel no longer under the level of the older people but are in the same level, including in terms of intellectual changes that appear from the way of thinking to achieve integration in social relationships with adults, which is a hallmark of adolescence development [6].

\section{GAME DESIGN}

In the process of designing the game Teen Society as a healthy social education game initially conducted data collection through interviews, literature studies and observations about teenage association. Next game design by determining the storyline, making game assets and the next process is part game programming, then testing game to check error or bug in game. And if there is an error then re-done until the game is ready to play.

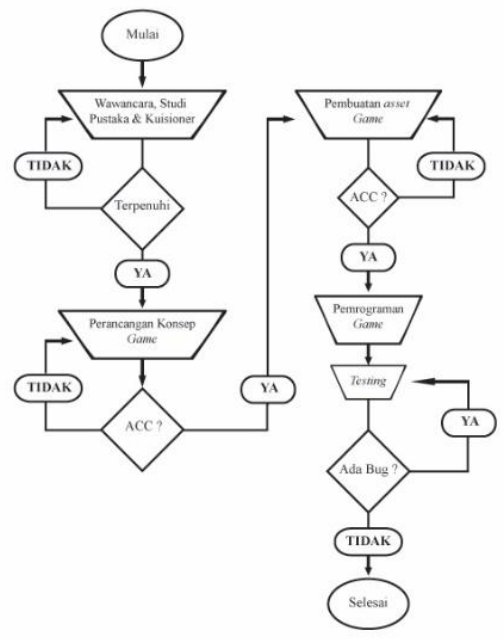

Gambar 1. Design Flow

\section{DESIGN PROCESS AND RESULT}

The process of making the game there are several steps that must be passed, namely: designing, asset creation, programming, and testing. By using these stages game creation will become more structured and efficient.

\section{A. DESIGN}

The first stage is the design of the game itself. Game design includes the determination of goals, themes, until the course of game 
applications. The main problem to be conveyed through Teen Society game is to improve the understanding of the respondents about the importance of aspects in the healthy association. (1) The financial aspect, aims to explain the importance of saving and managing finances in adolescence through a mini game shopping at the store of grandmother's grant money, (2) Social aspect, aims to explain the importance of helping others, through mini-games to grandmother to market, (3) The emotional aspect, aims to teach about the importance of managing emotions in adolescence in the face of problems through mini games quiz manages emotions, (4) Physical aspect, aims to teach about the importance of regulating healthy lifestyle through mini shopping game healthy food. (5) The aspect of sexuality, aims to teach about some sexual distortions to be avoided, through mini-games on the subject of sexuality.

Planning the path of Teen Society game application is to determine the basic concept of the game itself, the following is the basic concept of Teen Society game:

1. First, there is a quiz menu selection that contains about a number of questions concerning the problems of everyday life of adolescents and the end result will bring up the score or score obtained based on the aspect of healthy association. The quiz consists of 30 items of questions with two kinds of random answers. Points obtained from the choice of selected answers are concerned in what aspects.

2. Playing menus that have four kinds of mini games the first game that involves social as well as financial aspects, the second game about healthy lifestyle, then games that contain quizzes about adolescent sexual education, and quiz games about emotions.
This mini game is played when the player earns points on quiz games below average. So after the player plays the mini game points on one of the weak aspects will increase.

3. There is also a menu of information that contains glimpses of information about the financial aspects, social, emotional, physical, and aspects of sexuality.

\section{B. RESULTS}

In the making of the game requires the existence of an asset. Assets consist of all materials used in game making, such as background, button and sound. The game design results are as follows:

\section{Game Quiz}

In the game the color selection quiz is the dominant color of yellow and orange that shows joy and has a tolerant, investigative and prominent nature [7]. Figure 2 is a quiz game show, which consists of 30 questions and appears randomly. The player's job is to solve the question by balancing the five points above. Points earned should not be below the average of under 30 .

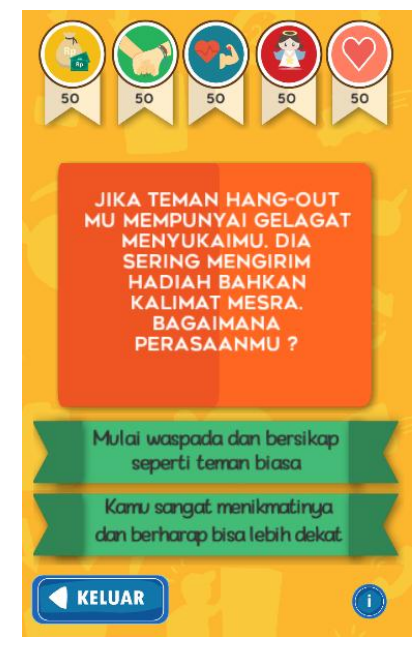

Figure 2. Display Game Quiz 


\section{Social Games}

Social games explain the concept of mutual help attitude, in this game describes the location on the highway. The player's job is to avoid various obstacles on the road by pressing the buttons to the left and right arrows to avoid obstacles. Figure 3 is a social gaming display.

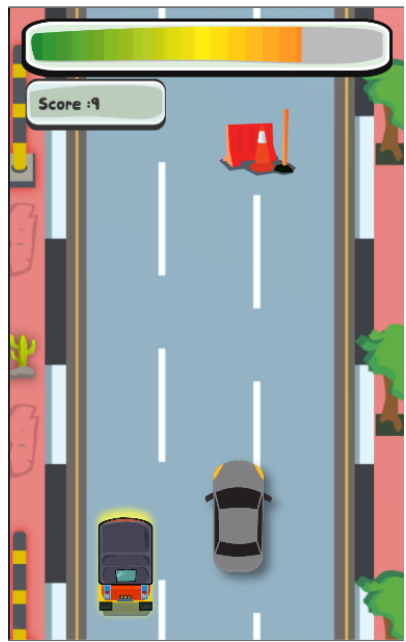

Figure 3. Social Gaming Display

\section{Financial Games}

Financial game explains about the concept of saving, on display this game describes the atmosphere was in the store or supermarket. The player's job is to manage the money he has in order to save.

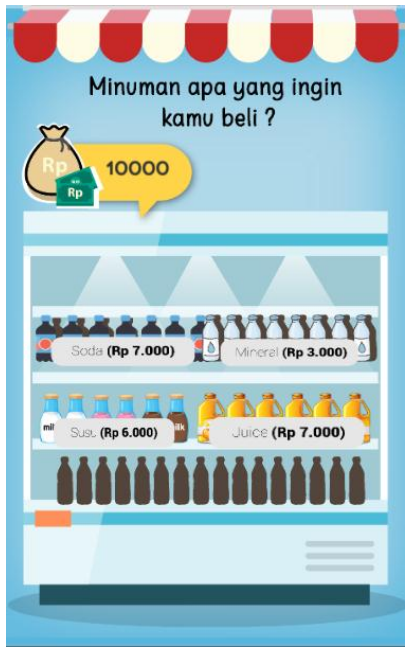

Figure 4 Display Game Financially

\section{Physical Games}

Physical games explain the concept of choosing healthy foods and avoiding fast food. The display of this game describes the atmosphere of players are shopping for food and drinks. The player's job is to avoid fast food, when players press the button to eat healthy then the points will increase, whereas when pressing the fast food button it will pop up the ban and the points will be reduced. Figure 5 is a physical game display.

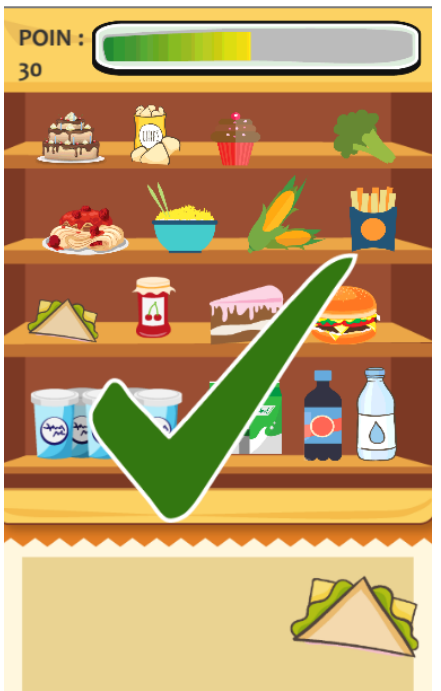

Figure 5. Display of physical games

\section{Emotion Games}

Emotion games explain the concept of how players tend to manage their emotions. The display of this game in the form of quiz games that contain about some examples of cases related to teen emotions and display a pop up that contains tips and tricks according to the selected answer. The player's job is to answer all the questions, after which the player will know the judgment through the star he gets. Figure 6 is an emotional game display. 


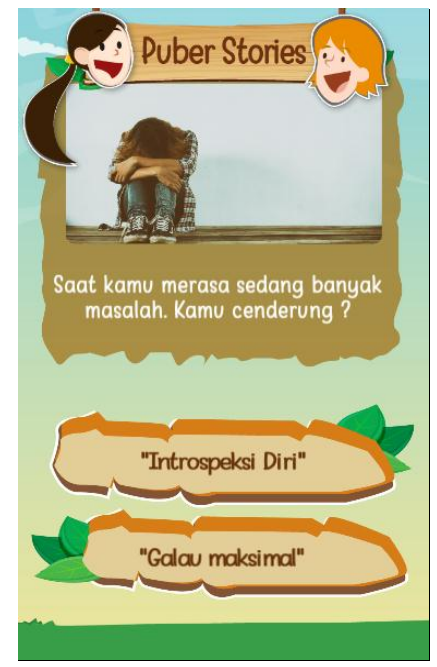

Figure 6. Emotion game display

\section{Sexuality Games}

The game of sexuality explains the concept of sex in adolescents based on prevailing norms in society. Display this game in the form of quiz games that contain about some examples of cases relating to teenage sexuality and display a pop up that contains tips and tricks according to the selected answer. The player's job is to answer all the questions, after which the player will know the judgment through the star he gets.

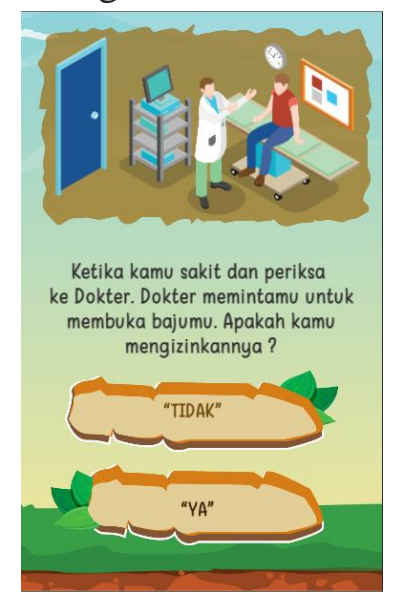

Figure 7. Sexuality Games Display

\section{CONCLUSIONS}

Based on this research, it can be concluded that the design of Teen Society game requires design stage which is designing game concept, asset creation, programming, and game testing.

\section{ACKNOWLEDGMENT}

Enggar Dwi Utami gratefully acknowledged to Beasiswa Unggulan scholarship support from Bereau for Planning and International Cooperation, Ministry of Education and Culture of Indonesia (Beasiswa Unggulan Kemendiknas Republik Indonesia).

\section{REFERENCES}

[1] J. Vol and E. Maret, "Upaya Meningkatkan Pemahaman Terhadap Materi Pergaulan Yang Sehat Pada Siswa," vol. 1, no. 1, pp. 163-173, 2016.

[2] M. Ihsan, "Pengaruh Terapan Media Internet dan Pola Pergaulan," Tsamrah al-Fikri, vol. 10, pp. 103-120, 2016.

[3] A. A. Nabila, Anisa Ismi and Nugroho, "Pengaruh Pemberian Pelatihan Asertivitas Terhadap Kecenderungan Kenakalan Remaja Pada Siswa Kelas X Sekolah Menengah Kejuruan (SMK) Bhinneka Karya Surakarta," Wacana, vol. 4, pp. 1-36, 2012.

[4] S. Mahendra, "Hubungan Antara Pola Asuh Orang Tua Dan Pergaulan Peer Group (Kelompok Sebaya) Dengan Sikap Pada Siswa Kelas Xi Ips Sma Negeri 3 Surakarta Tahun Ajaran 2009/2010," Universitas Sebelas Maret Surakarta, 2010.

[5] F. N. Hamdan, "Persepsi masyarakat terhadap pergaulan mahasiswa kost di rt 
003 rw 03 kelurahan cempaka putih kecamatan ciputat timur," Universitas Islam Negeri Syarif Hidayatullah Jakarta, 2016.

[6] E. B.Hurlock, Psikologi Perkembangan, 5th ed. Jakarta: Erlangga, 1992.

[7] S. Utami and H. Habsari, "Aplikasi semiotik \& efek psikologis tampilan warna pada rumah minimalis," Riptek, vol. 4, no. 1, pp. 37-44, 2010. 